\title{
A theoretical framework to adopt collaborative initiatives in supply chains
}

\section{Estrutura teórica para a adoção de iniciativas de colaboração em cadeias de suprimentos}

GESTÃO PRODUCÃ̃O

ISSN 0104-530X (Print) ISSN 1806-9649 (Online)

\author{
Denise Cervilha de Freitas ${ }^{1}$ (1) \\ Leandro Gomes de Oliveira ${ }^{2}$ (1) \\ Rosane Lúcia Chicarelli Alcântara ${ }^{2}$
}

How to cite: Freitas, D. C., Oliveira, L. G., \& Alcântara, R. L. C. (2019). A theoretical framework to adopt collaborative initiatives in supply chains. Gestão \& Produção, 26(3), e4194. https://doi.org/10.1590/0104-530X-4194-19

\begin{abstract}
Collaborative initiatives emerged in the 1980s as a means to increase inter-organizational cooperation, thereby achieving performance improvements in supply chains. Despite this, no consensus exists among researchers with respect to which collaborative initiatives should be deployed along a supply chain. This study analyzes five collaborative initiatives - Quick Response (QR), Efficient Consumer Response (ECR), Continuous Replenishment Program (CRP), Vendor Managed Inventory (VMI) and Collaborative Planning, Forecasting and Replenishment (CPFR) - by conducting a systematic literature review, aiming to develop a theoretical framework to guide the decision-making process of adopting and implementing these initiatives. Based on the characteristics of the collaborative initiatives, expected benefits, reasons for adopting, and possible barriers found in the literature review, a theoretical framework was developed as a flowchart, clearly indicating to decision-makers the main aspects of concern when adopting one or more collaborative initiatives and highlighting the need to constantly monitor the chosen initiative's performance.
\end{abstract}

Keywords: Collaboration; Collaborative initiatives; Theoretical framework; Supply chain; CRP; CPFR; ECR; QR; VMI.

Resumo: As iniciativas de colaboração surgiram nos anos 1980, como forma de aumentar os níveis de cooperação entre organizações, proporcionando melhorias no desempenho da cadeia de suprimentos. Apesar disso, não há um consenso entre os pesquisadores sobre quais iniciativas colaborativas devem ser implantadas ao longo da cadeia de suprimentos. Este trabalho analisou cinco iniciativas de colaboração por meio de revisão sistemática da literatura: Quick Response (QR), Efficient Consumer Response (ECR), Continuous Replenishment Program (CRP), Vendor Managed Inventory (VMI) e Collaborative Planning, Forecasting and Replenishment (CPFR), com o objetivo de propor uma estrutura teórica para orientar o processo decisório de adoção e implementação dessas iniciativas colaborativas. Baseado nas caracteristicas, benefícios esperados, motivadores à adoção e possíveis barreiras das iniciativas de colaboração, encontrados na revisão da literatura, a estrutura teórica foi elaborada. A mesma foi proposta como um fluxograma, mostrando ao tomador de decisão os principais aspectos que devem ser analisados para a adoção de uma, ou mais, iniciativas de colaboração, e evidenciando a necessidade de monitoramento constante do desempenho da iniciativa.

Palavras-chave: Colaboração; Iniciativas de colaboração; Estrutura teórica; Cadeia de suprimentos; CRP; CPFR; ECR; QR; VMI.

\section{Introduction}

Efficient supply chain management (SCM) has become a valuable means to gain competitive advantage and improve company performance (Castro \& Ladeira,
2012). To achieve this level of efficiency, inter-partner collaboration has emerged to enhance SCM (Vigtil \& Dreyer, 2008; Yao et al., 2007), guaranteeing

\footnotetext{
${ }^{1}$ Instituto Federal de Educação, Ciência e Tecnologia do Sul de Minas Gerais - IFSULDEMINAS, Av. Maria da Conceição Santos, 900, Bairro Parque Real, CEP 37560-260, Pouso Alegre, MG, Brasil, e-mail: denise.freitas@ifsuldeminas.edu.br

${ }^{2}$ Departamento de Engenharia de Produção, Universidade Federal de São Carlos - UFSCar, Rodovia Washington Luís, Km 235, São Carlos, SP, Brasil, e-mail: leandrobaquim@yahoo.com.br; rosane@dep.ufscar.br
}

Received July 31, 2017 - Accepted Sept. 6, 2018

Financial support: Brazilian Coordination for the Improvement of Higher Education Personnel (CAPES). 
greater flexibility to address market changes, waste reduction, responsiveness, and improved customer satisfaction (Gao et al., 2005; Mentzer et al., 2001).

Collaboration occurs when two or more organizations exchange information, sharing the responsibility to plan, manage, execute, and monitor supply chain performance (Cao \& Zhang, 2011). To share their information with the aim to collaborate, companies employ various collaborative initiatives, such as Collaborative Planning (CP), e-Collaboration (Chong et al., 2009), Collaborative Agent Time (CAT) (Carle et al., 2012), Value Chain Analysis (VCA) (Francis et al., 2008), Generic Product Family Model (GPF) (Jiao et al., 2007), Collaborative Transportation Management (CTM) (Chan \& Zhang, 2011), Quick Response (QR) (Choi \& Sethi, 2010), Efficient Consumer Response (ECR) (Kurnia \& Johnston, 2003), Continuous Replenishment Program (CRP) (Raghunathan \& Yeh, 2001), Vendor Management Inventory (VMI) (Freitas et al., 2014), and Collaborative Planning Forecasting Replenishment (CPFR) (Fu, 2016; Marqui et al., 2013). However, according to Gomes \& Kleimann (2015) and Freitas et al. (2018), the best known collaborative initiatives in both the corporate and academic environment are QR, ECR, CPR, VMI, and CPFR.

Holweg et al. (2005) stated that collaborative initiatives have been addressed by academics and consultants in the field of SCM since the mid-1990s. However, despite the success stories that have been reported in the literature and the simplicity of the concepts, many implementations are not satisfactory, considering the benefits that are initially expected. According to these authors, one reason for this is that collaborative initiatives are not well understood and the concepts are not as well defined as they should be. Moreover, the complexity of current supply chains makes it difficult to select the best approach that combines the benefits of collaboration with the production and internal inventory management processes. Panahifar et al. (2015), speaking specifically about the CPFR, commented on the results of implementing this initiative that don't live up to expectations in the reality of companies, attributing them to the lack of jobs and focusing on the facilitators and barriers of this initiative.

Ellram \& Cooper (1990) have emphasized that although most partnerships exhibit common elements and characteristics, there is no ideal model that can be deemed appropriate in any given context. Mentzer et al. (2000) considered the need to analyze the market environment to design the best form of partnership, thereby choosing a strategic partnership or an operational one. In a complementary way, Sari (2008), examining the literature on SCM, posited that there is no consensus among researchers with respect to which collaborative initiatives should be implemented along a supply chain.

The fact that several studies approach collaborative initiatives as a stand-alone topic (Freitas et al., 2018) and that the nature of this research field is quite fragmented, with divergent opinions, hinders the evolution of this study area. Given the latent need for parameters to assist in choosing the most appropriate collaborative initiative, this article aims to propose a theoretical framework to guide the decision-making process of adopting and implementing collaborative $S C M$ initiatives, more specifically $Q R, E C R, C R P$, $V M I$ and $C P F R$, based on their characteristics, expected benefits, motivators for adoption, and barriers encountered.

According to Torraco's (2005) classification, this paper presents a conceptual framework, which expands the existing theoretical knowledge about the five selected collaborative initiatives of SCM, contributing to the development of this study area. From a practical point of view, understanding the characteristics, benefits, barriers, and motivators of the studied collaborative initiatives together with a theoretical framework to guide their adoption can assist managers in implementing collaborative initiatives in their supply chains. The expected result of this implementation depends on the choice of the most appropriate initiative(s) for the context and reality of a particular enterprise.

In addition to this introductory section, this article is organized into six sections. The second section presents the theoretical framework, succinctly discussing SCM, collaborative supply chain management, and collaborative initiatives. The third section addresses the methodological procedures that were used in this study, specifically a systematic literature review. The fourth section highlights the characteristics, benefits, motivators, and barriers of each collaborative initiative, which supported the construction of the theoretical framework presented in the fifth section. The sixth section presents the study's final considerations.

\section{Theoretical framework}

The theoretical foundations of this study are based on the theories of SCM, collaborative SCM, and collaborative initiatives.

\subsection{Supply chain management}

Market evolution, globalization, growing consumer demands, accrued competition, downward pressure on prices, awareness of environmental preservation, rapid technological changes, improved availability of information, and the introduction of short-life products (Freitas, 2015) have called for greater flexibility from organizations and the search for 
differentiated strategies; hence, there is now a need to develop coordination and collaboration mechanisms for suppliers and distributors. This will not only make products available at the right time and the right place for consumption (Lima et al., 2016) but will also allow supply chain agents to obtain better socio-economic benefits.

The concept of SCM has emerged to remedy the chain's imperfections and for this reason has consolidated itself in recent decades (Tanaca et al., 2014). Even though this concept first appeared in the early 1980s (Mentzer \& Gundlach, 2010), with logistics consultants Oliver and Weber, it was only in the 1990s that it received the attention of researchers and practitioners (Kozlenkova et al., 2015). Since then, researchers have tried to understand and explain how organizations should integrate activities and coordinate flows to better meet market needs (Aspargi et al., 2016).

Although there is no universal definition of SCM, various perspectives have resonated among researchers and practitioners (Esper et al., 2010). SCM has emerged to cope with a complex environment to plan, manage, coordinate, and integrate business activities, seeking to meet customer requests while striving for better competitive advantages (Lakshmanasamy \& Anil, 2015). It can be defined as the systematic and strategic coordination of traditional business functions within and between organizations with the aim of improving the long-term performance of companies and the chain as a whole (Vallet-Bellmunt et al., 2011).

SCM comprises integrated activities related to the transformation and flow of goods, services, and information from the sources of the materials to end users (Ogunlela \& Lekhanya, 2016). It integrates the eight business processes (customer relationship management, customer service management, demand management, order fulfillment, manufacturing flow management, supplier relationship management, product development and commercialization, and returns management) conducted by two or more organizations, upstream and downstream, that have the same objectives pertaining to the flow of products, services, finances, and information (Goldsby \& García-Dastugue, 2003; Moura, 2013). Following this method, the companies that comprise a supply chain must organize and practice their activities collaboratively to meet end-consumer demands, thereby increasing their market share.

\subsection{Collaborative supply chain management}

Recent decades have witnessed the need for companies to seek external opportunities to collaborate with partners to ensure that supply chains are operating efficiently and responding to market needs (Cao \& Zhang, 2011). Companies have begun to realize that closer relationships and information sharing can improve the quality of decision-making, reduce demand uncertainty, and ultimately enhance SCM as a whole (Whipple \& Russell, 2007).

Collaborative SCM emerged in the 1990s as an evolved form of the Just in Time (JIT), Electronic Data Exchange (EDI), and Quick Response (QR) approaches (Gomes \& Kleimann, 2015). A collaborative supply chain comprises two or more companies working together to plan and execute supply chain activities to achieve greater success than when acting alone (Fawcett et al., 2008).

Collaboration occurs when these institutions agree on established objectives and use their resources (information, people, technologies) to share the responsibility to plan, manage, and execute supply chain operations (Gomes \& Kleimann, 2015), thereby creating synergies and achieving long-term competitive advantage (Melo \& Alcântara, 2016). However, collaborations are much more complex, going beyond information exchange and requiring a set of techniques and systems as well as individual behaviors and skills (Marqui et al., 2013).

According to Marqui et al. (2013), collaborative relationships are characterized by communication, interdependence, transparency, flexibility, leadership, synchronized decision-making, commitment, and organizational culture compatibility. To achieve a steady collaborative relationship, the following factors (or behaviors) should also be considered: information sharing, investment in information technology, joint planning, adoption of common goals and objectives, adoption of a standardized performance measurement model, cross-functional integration, development and maintenance of long-term relationships, and training.

Freitas et al. (2014) suggested that collaboration elements can be embedded into three levels, namely, interpersonal, tactical, and strategic. At the interpersonal level, the collaborative elements are represented by trust, commitment, interdependence, transparency, flexibility, and reciprocity. At the tactical level, collaboration refers to joint actions, equitable cost, risk and benefit sharing, and logistical and business information sharing. Finally, at the strategic level, collaboration involves inventory information sharing, knowledge of partners' difficulties and strategies, relationship history, and involvement of top management.

According to Cao \& Zhang (2011), collaborative relationships can facilitate organizations to share risks, access complementary resources, reduce transaction costs, and improve the productivity, profitability, and competitive advantage of both a company and its supply chain. Gomes \& Kleimann (2015) stated that collaboration among supply chain partners improves efficiencies, flexibility, and sustains competitive 
advantages. Furthermore, Nyaga et al. (2010) discovered that companies involved in collaborative relationships achieved better visibility and higher levels of service, flexibility, quality, process capability, and consumer satisfaction.

Nonetheless, it should be noted that companies must adopt collaborative initiatives appropriate to the reality of their supply chain. Each collaborative initiative demands a specific technological, operational, knowledge, and behavior level from the involved organizations, with greater efficiency gains being achieved through the best applicability of these initiatives.

\subsection{Collaborative initiatives}

The Quick Response (QR) strategy began to develop in the mid-1980s in the textile sector (Birtwistle et al., 2003; Choi \& Sethi, 2010) as a strategy to reduce lead time and improve supply flexibility (Yang et al., 2015). Supply chain members no longer use orders from their immediate customers as the only source of information to schedule their production and stock replenishment. They now have visibility into the final demand, being able to observe actual market behavior and respond more quickly to it. Production is driven by demand, and the aid of information systems and technologies is very important (Forza \& Vinelli, 1997). Finally, supply chain companies must shape themselves through a quick response culture, leaving the traditional view of local profit optimization toward systemic thinking approach, considering the interest of the whole supply chain (Perry \& Sohal, 2000).

Later, in the early 1990s, the non-durable consumer goods sector began to undergo profound transformations, causing food retailers to develop strategies to remain in the market (Alvarado \& Kotzab, 2001). In this context, the Efficient Consumer Response (ECR) movement emerged, consisting of four main strategies, which have been listed as follows, to better serve end consumers: efficient replenishment, efficient promotion, efficient new product introductions, and efficient product assortment. Standard methods (European Article Numbering-EAN, Electronic data interchange-EDI, Information System-IS, etc.) are encouraged, allowing the simplification of information and commodity flows (Alvarado \& Kotzab, 2001; Kotzab, 1999). To implement these strategies, several practices are proposed, such as the Continuous Replenishment Program (CRP) for efficient replenishment and category management to deal with other strategies (Kurnia \& Johnston, 2003).

The initiatives of the Continuous Replenishment Program (CRP) and Vendor Managed Inventory (VMI) began to develop in the 1990s. In this work, the VMI is considered as a way to operationalize the $\mathrm{CRP}$, the latter being an application of the efficient replenishment strategy proposed by the Efficient Consumer Response (ECR). The CRP introduces innovations in three areas: processes, responsibilities, and price policies (Lee et al., 2003). With real-time access to the customer's inventory level, the CRP focuses on improving the flow of products in a supply chain, increasing replenishment frequencies. As a result, responsibilities for purchasing decisions and inbound logistics are transferred from the customer to the supplier as long as the latter minimizes the inventory and stockouts. Furthermore, as the order frequency increases, purchasing policies based on promotions and price changes are virtually eliminated, allowing suppliers to maintain a constant price throughout the period in which there is still collaboration between companies that use the collaborative tool in question, thus enabling better planning and synchronization of production with real demand. This new pricing policy is known as Everyday Low Price (EDLP) or Everyday Low Cost (EDLC), as stated by Raghunathan $\&$ Yeh (2001).

Finally, Collaborative Planning, Forecasting, and Replenishment (CPFR) is a business practice that has been developed to eliminate some problems that are encountered in VMI and CRP, such as the influence of competitor promotions and actions, changes in demand patterns, and the problems of individual forecasts (Barratt \& Oliveira, 2001; Stank et al., 1999). Although the ECR had already considered issues such as the promotion and assortment of products, plans, and forecasts were still worked on individually. Thus, CPFR was developed to suggest that supply chain partners should work together to develop a business plan and conduct forecasts collaboratively by identifying exceptions and working on them to reach a consensus and plan and execute replenishment (Stank et al., 1999).

\section{Methodology}

This study conducted a systematic literature review to forge a theoretical basis to fulfill its objectives. This systematic review explains to the reader the decisions regarding the selection of databases, publications, keywords, search periods, thereby allowing the reader to evaluate the validity of this research, that is, if the review was conducted correctly. Moreover, it ensures that this study can be replicated by documenting its search process, conferring reliability to the process (vom Brocke et al., 2009). This study was based on the five steps to conduct a review that were proposed by Denyer \& Tranfield (2009) (Figure 1).

The research question that guided the literature review process of this study has been provided as follows: What are the characteristics, benefits, barriers, and motivators of $Q R, E C R, C R P, V M I$, and CPFR collaborative initiatives in supply chains? The characteristics of these collaborative initiatives entail the areas of operation, mode of operation, components, and strategies; the benefits correspond 
to the results of using the initiative; the motivators involve factors outside a company that contribute to adopting the initiative, whereas barriers include all factors that can hinder the process of implementing an initiative.

The second step of this study corresponds to finding the studies that would aid us in identifying the keywords (Colicchia \& Strozzi, 2012) of this study topic and selecting databases to gather information (Wong et al., 2012). In general, the searches were conducted using the name of the collaborative initiative or its acronym in the main parts of the article (title, abstract, and

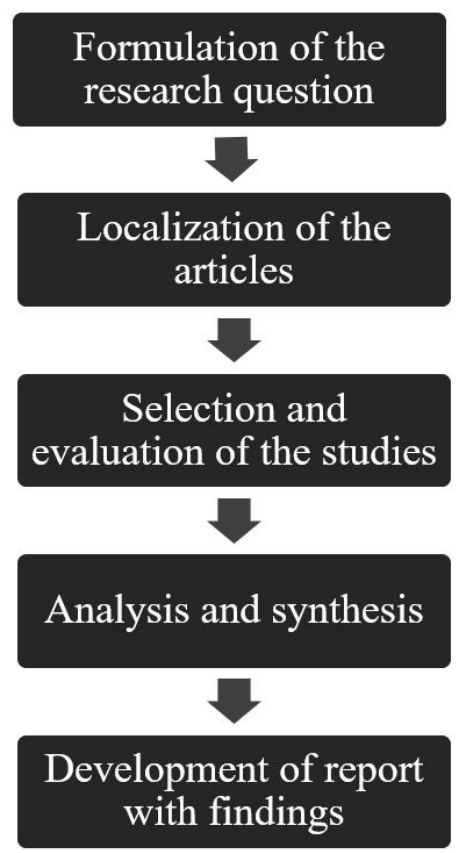

Figure 1. Steps of systematic literature review. Source: Denyer \& Tranfield (2009). keywords) together with the keywords "supply chain" and collabo* anywhere in the article, including social sciences, engineering, and humanities as subareas. Five databases were selected to develop this research: Scopus, Web of Science, EBSCOhost, Emerald, and SciELO. Scopus and Web of Science were selected based on the work of Buchinger et al. (2014), which list them as important search mechanisms, as they have innumerable resources capable of facilitating and increasing the quality of academic work. On the other hand, EBSCOhost and Emerald were selected because the former has greater coverage in the area of supply chains (Wong et al., 2012) and the latter presents articles that don't show up when searching other databases. Finally, the SciELO database was selected in an attempt to identify the studies of Brazilian authors.

In the third stage - the selection and evaluation of the studies - the inclusion and exclusion criteria were outlined to select the most important and relevant documents for this research (Colicchia \& Strozzi, 2012; Denyer \& Tranfield, 2009). The searches were conducted between January and July 2014, and they were updated in January 2015 and again in August 2018. Documents that were not articles or revisions were excluded to increase the quality of this research, because they usually are not peer evaluated (Fischl et al., 2014; Seuring \& Gold, 2012). Only articles in Portuguese or English were selected, which guarantee a good representation of the subject under review. Duplicate articles have been removed, and only the texts available for download have been kept. Finally, the texts were read in full, and those that did not present relevant contributions to the areas of characteristics, benefits, barriers, and motivators were excluded. In all, 154 papers were selected for this study (Table 1).

Table 1. Final search results.

\begin{tabular}{|c|c|c|c|c|c|c|c|}
\hline & & & QR & ECR & CRP & VMI & CPFR \\
\hline \multirow[t]{6}{*}{ SEARCH TERMS } & \multirow{6}{*}{$\begin{array}{l}\text { Search criteria: Title or acronym of the } \\
\text { initiative in the title, abstract and/or } \\
\text { keyword AND "supply chain" AND } \\
\text { collabo* anywhere in the article }\end{array}$} & Scopus & 60 & 34 & 25 & 156 & 115 \\
\hline & & Web of Science & 11 & 11 & 8 & 64 & 82 \\
\hline & & EBSCOhost & 6 & 8 & 7 & 68 & 50 \\
\hline & & Emerald & 5 & 18 & 8 & 14 & 15 \\
\hline & & SciELO & 42 & 58 & 2 & 26 & 2 \\
\hline & & Total & 124 & 129 & 50 & 328 & 264 \\
\hline \multirow{6}{*}{$\begin{array}{l}\text { INCLUSION } \\
\text { CRITERIA }\end{array}$} & \multirow{6}{*}{$\begin{array}{l}\text { Type of document: articles, reviews; } \\
\text { Language: English, Portuguese; } \\
\text { Text available for download }\end{array}$} & Scopus & 22 & 20 & 16 & 77 & 36 \\
\hline & & Web of Science & 5 & 8 & 6 & 36 & 21 \\
\hline & & EBSCOhost & 3 & 4 & 2 & 29 & 11 \\
\hline & & Emerald & 5 & 16 & 5 & 15 & 18 \\
\hline & & SciELO & 0 & 6 & 0 & 3 & 2 \\
\hline & & Total & 35 & 54 & 29 & 160 & 88 \\
\hline \multirow{4}{*}{$\begin{array}{l}\text { EXCLUSION } \\
\text { CRITERIA }\end{array}$} & Duplicate Removal & & 27 & 45 & 17 & 110 & 49 \\
\hline & Content Evaluation (Summary) & & 10 & 36 & 5 & 84 & 44 \\
\hline & Content Evaluation (Read in full) & & 9 & 33 & 4 & 73 & 41 \\
\hline & & TOTAL & \multicolumn{5}{|c|}{154 documents } \\
\hline
\end{tabular}


In the analysis and synthesis step, the relevant data was extracted from the literature, synthesized, and evaluated (Okoli \& Schabram, 2010). For each initiative, the four categories (characteristics, barriers, benefits, and motivators) were extracted from the documents. To analyze the content of the revised material, the content may be separated into dimensions and categories. According to Seuring \& Gold (2012), these dimensions or categories (called grouping criteria here) can be created inductively or deductively. In the deductive approach the categories are evaluated prior to material analysis based on existing theory, whereas in the inductive approach, the categories result from an iterative process of construction, testing, and revision and are derived from the analyzed material.

The characteristics were analyzed in an unstructured manner (inductive approach), and it should be noted that no classification or grouping factor was elaborated a priori. Subsequently, the identified barriers, benefits, and motivators were grouped through an iterative process (deductive-inductive) to ensure that the created constructs were representative, not repetitive. It is worth emphasizing that the objective of this analysis was to raise the possible barriers, benefits, and motivators of the initiatives and, therefore, the factors found during the bibliographic review received the same importance as the factors mentioned during case studies, surveys, simulations, modeling, etc.

The analysis of these categories revealed that the nomenclatures used by the authors in this field were diverse and often similar in their sense. It was necessary to group elements with similar meanings. For this purpose, the works of Fawcett et al. (2008), Marqui et al. (2013), and Mentzer et al. (2001) were selected as a basis for grouping the various elements (deductive approach).
Finally, it was ensured that the whole process of systematically reviewing the literature was reported with the highest level of detail possible by means of a report containing the results, thereby ensuring the reproduction of the study and presentation of its conclusions (Okoli \& Schabram, 2010).

\section{Results}

The studies on the collaborative initiatives addressed in this work began in 1997 with the QR and ECR initiatives. Figure 2 displays the distribution of the selected article samples in the systematic literature review by year and by initiative. In this chart, it is possible to verify that 2008 was the year with the highest number of publications in the subject under review. In addition, the chart indicates the predominance of ECR-related publications between 1997 and 2004 with a drop in the number of articles after that. Meanwhile, the number of publications pertaining to VMI and CPFR has grown over the years.

Among the authors who have discussed several initiatives concomitantly are Derrouiche et al. (2008), who addressed the QR, ECR, and CRP initiatives, Holmström et al. (2002), who focused on ECR and CPFR, and Alftan et al. (2015), Hudnurkar \& Rathod (2012), and Ramanathan (2014), who have worked with VMI and CPFR.

The most relevant periodicals in this field are the International Journal of Physical Distribution and Logistics Management, with 14 articles in this area, Supply Chain Management: An International Journal, with 11 articles, International Journal of Production Economics, with 10 published articles, International Journal of Advanced Manufacturing Technology, International Journal of Retail and Distribution Management, Industrial Management and Data Systems, each having published four articles,

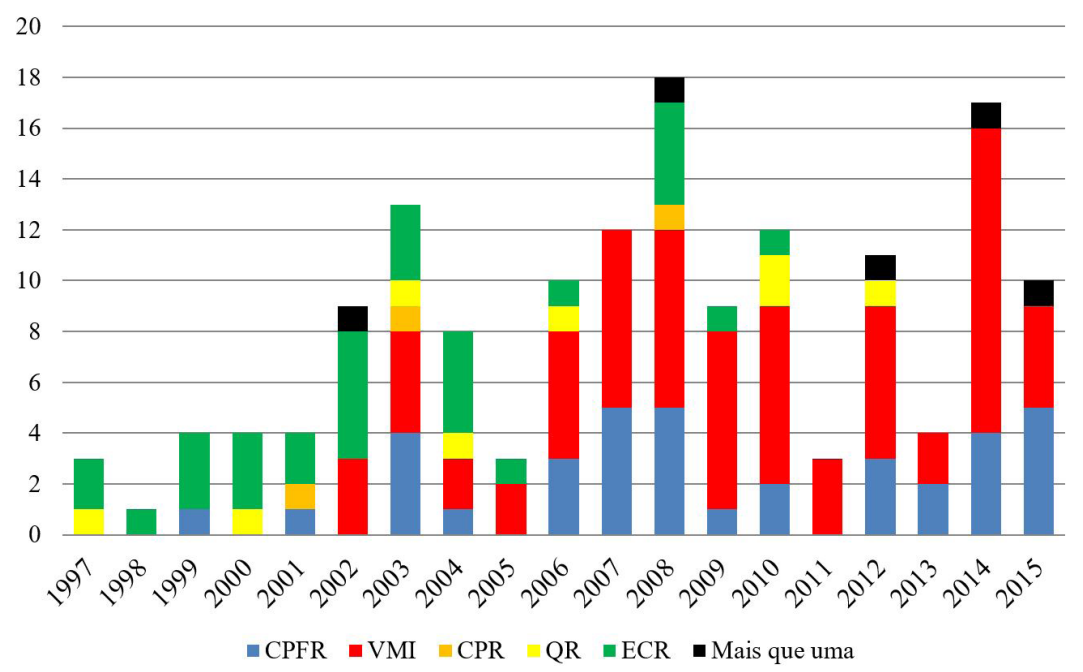

Figure 2. Distribution of articles by year and by Collaborative Initiative. Source: Prepared by the authors. 
International Journal of Management Science, European Journal of Operational Research, Journal of Enterprise Information Management, International Journal of Operations and Production Management, and Revista de Administração Contemporânea, each having published three articles in this field. Other magazines have published up to two articles in this field.

\subsection{Characterization of collaborative initiatives}

To characterize the collaborative initiatives used in supply chains, a framework was developed with several dimensions, outlining the different possible configurations for each studied initiative, as shown in Figure 3. These dimensions were created to highlight the similarities and differences between the collaborative initiatives; they were organized into five groups: information, inventory, replenishing, planning, and supply chain activities.

The framework proposed in this study is an expansion of the one presented by Elvander et al. (2007), which is specific to the VMI initiative. The structure of the framework provided by these authors, as well as part of their nomenclature and layout of the elements were maintained. The content, however, was expanded, encompassing other initiatives and adapting it to the needs of the present study. This was done because, when analyzing the initiatives of collaboration in a

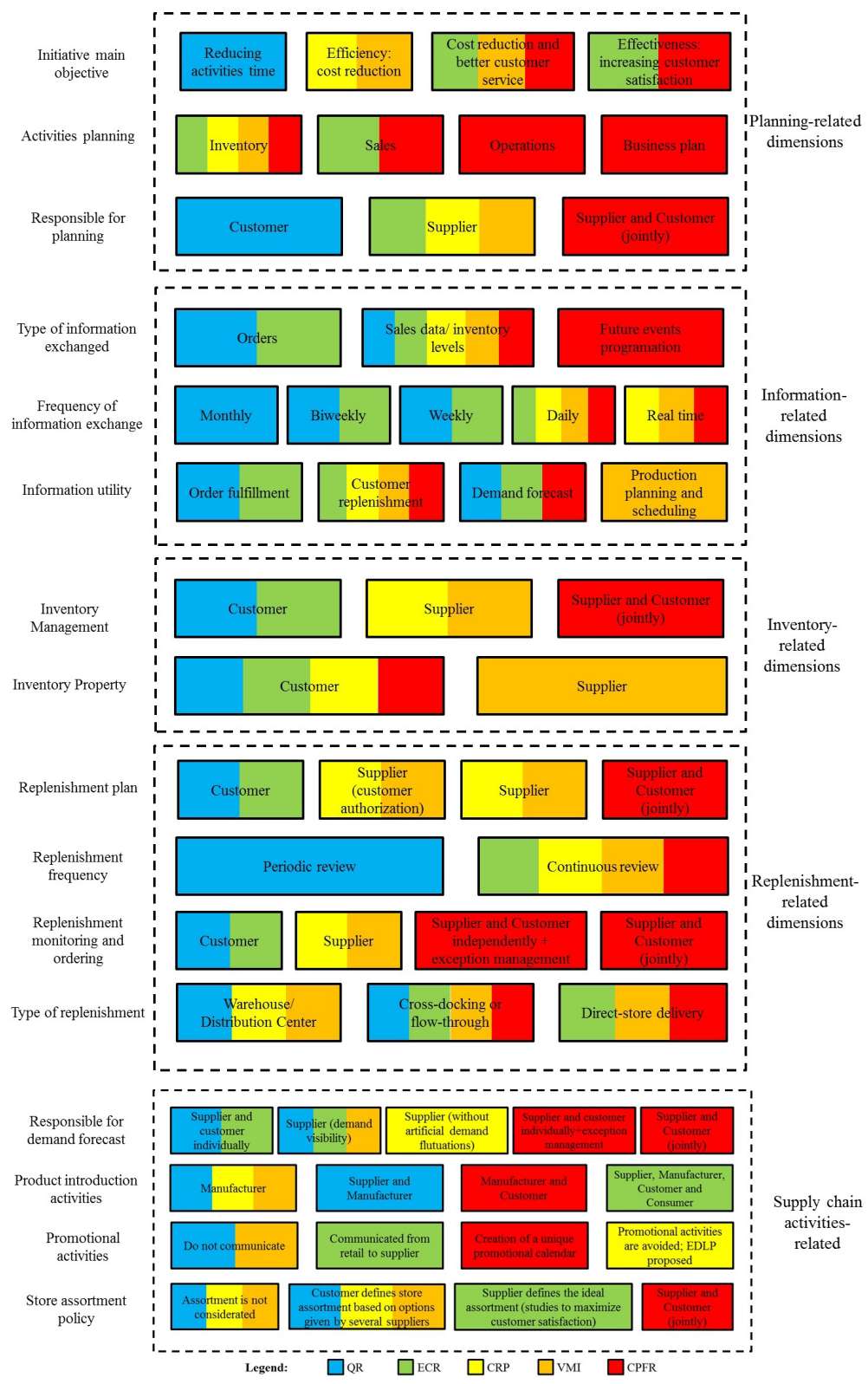

Figure 3. Framework for characterizing collaborative initiatives. Source: Prepared by the authors. 
supply chain, it is necessary to include, besides the VMI-focused only on replenishing - other more encompassing initiatives, mainly ECR and CPFR, which deal with aspects such as promotions, assortment, and planning, which have not been addressed by authors dealing with VMI.

\section{- Planning-related dimensions:}

Main objective of the initiatives: The main objective is to reduce activity time to allow greater flexibility in relation to market demands, efficiency (related to cost reduction) or effectiveness (related to increased consumer satisfaction).

Activity planning: In the early stages of collaboration, only inventory and replenishment activities are planned to optimize the inventory level throughout a supply chain. With the evolution of collaboration, sales activities begin to be planned by the members of a supply chain. The most advanced planning level includes the business plan, which establishes the guidelines to be met by the partners to achieve the proposed objectives of the collaborative relationship.

Responsible for planning: With respect to QR, the client is the one who realizes the plans, keeping the consumers in mind. In CRP and VMI, the responsibility of planning the inventory is transferred to the supplier, and in the ECR, the responsibility of category management is the supplier's, who has a more in-depth knowledge of its products. Finally, in CPFR, all activities are jointly planned by the customer and supplier, always keeping in mind the final consumer and the best interest for the supply chain as a whole.

\section{- Information-related dimensions:}

Type of information exchanged: Traditionally, only information containing purchase orders is shared among the companies in a supply chain; this is responded with a product flow according to the requested order. As partners begin to relate to their customers and suppliers, they also share information on current sales history and inventory level, providing greater visibility of demand to the further upstream supply chain, thereby reducing the bullwhip effect. At the most advanced level of collaboration, companies also begin to share future data, sharing their plans for upcoming periods, such as promotions, events, fairs, etc.

Frequency of information exchange: The frequency of information exchange involves data related to sales history, inventory level, and/or ordering. Data related to sales history and inventory level can be shared on regularly or in real time to provide partners with demand visibility. However, in some cases, either due to the lack of technology or the initial stage of collaboration, a lower frequency of information exchange may be sufficient.

Use of information: The way the shared informed is used also varies between the collaborative initiatives. At an early stage, the information (order request) is used only for order fulfillment. Following this, the vendor begins to use the sales histories and inventory level to schedule customer replenishing. As the relationship evolves, the information is used to forecast demand. The most advanced stage involves the use of all the shared information to plan and schedule production - one of the proposals of VMI.

\section{- Inventory-related dimensions:}

Inventory management: The person in charge of managing the inventory at the customer's premises in the QR and ECR is the customer. In CRP and VMI, on the other hand, this authority is transferred to the supplier, and in CPFR, the responsibility of inventory management is shared between the customer and supplier.

Inventory ownership: This factor differentiates VMI from other initiatives: in VMI, inventory ownership at the customer's premises is the supplier's consignment, but in practice, this does not happen often.

\section{- Replenishment-related dimensions:}

Replenishment plan: This determines the replenishment frequency and minimum and maximum inventory limits. This plan can be outlined either by the customer or the supplier, but the customer's review and authorization are mandatory. Outlining this plan may also be solely the responsibility of the supplier or, at a more advanced level of collaboration, performed by the customer and supplier together in accordance with the business objectives.

Replenishment frequency: Replenishment can be periodic or continuous. It is expected that with the advancement of information technologies, the monitoring of inventory levels for replenishment will become continuous. In Figure 3, it was decided to relate the periodic revision to $\mathrm{QR}$, as this initiative was well established in the textile industry with seasonal trends, replenishment of the products at the beginning of each season with only supplementary requests made later being common. In the consumer goods industry, on the other hand, other initiatives have been established as a priority. The high turnover characteristic of products in this industry makes a continuous review more adequate.

Monitoring and replenishment orders: Inventory monitoring and the establishment of replenishment orders can be performed either by the customer, as it occurs in the QR and ECR initiatives, or by the supplier, as it occurs in the CRP and VMI, or jointly by the customer and supplier, as it occurs in the CPFR. 
Replenishment type: Suppliers can replenish the customer's warehouse or distribution center who then replenishes his stores or units. Replenishment can also be directly performed by the supplier in the stores or customer units. An alternative to these two forms is the cross-docking or flow-through practice, in which the supplier delivers to the customer's distribution center or warehouse and, without the need for storage; the products are directed to the customers' stores.

\section{- Supply-chain activity dimensions:}

Demand forecast responsibility: Demand forecasting can be performed independently either by the supplier or the customer. The supplier can predict demand by using the information he receives from the end consumer. In the CRP, the supplier excludes behaviors that generate artificial demand fluctuations, such as the early purchase of large volumes at a discounted price. In CPFR, demand forecasting can be performed individually or jointly by the customer and supplier.

New product introduction activities: These active can only be conducted by the product manufacturers. The raw material supplier can also be involved in the process, suggesting new raw material alternatives for a better cost-benefit ratio. In CPFR, both the manufacturer and customer think together to design new products that meet the needs of end consumers. Finally, in the ECR, in a more integrated way, all companies in a supply chain are encouraged to be included in the process, keeping in mind the needs of the final consumer.

Promotional activities: These activities are conducted independently by the customer and not communicated to the supplier in QR and VMI. In ECR, promotions are communicated to the supplier and planned by the customer, aiming to increase the efficiency of the promotional activities. CPFR proposes the creation of a unique promotional calendar between the client and suppliers to allow replenishment and sales forecasting activities to be planned. CRP, however, avoids promotional activities, encouraging demand to behave as smoothly and realistically as possible.

Product assortment policy: In the early stages of collaboration, increased product availability is stimulated without reducing the variety offered to consumers. Traditionally, the assortment is defined by the retailer based on the options offered by his various suppliers. In the more developed stages, the supplier begins planning the assortment based on his knowledge of the market of his products, with the objective of maximizing sales according to the expectations of the final consumer. In CPFR, the customer and supplier should plan the assortment together, combining their expertise with respect to market knowledge and consumer needs.

In Figure 3, each collaborative initiative is represented by a distinct color, and for each dimension, the most likely characteristics of each initiative are differentiated by their respective colors. It is important to emphasize that collaborative initiatives can have different configurations, depending on the companies' objective and the environment in which they are inserted. Furthermore, for each dimension, the elements have been arranged in such a way that a more developed level of collaboration was located to the right of the figure and the less developed ones remained more to the left.

\subsection{Benefits}

After analyzing the benefits of the studied collaborative initiatives, benefits which were identified during the systematic review of the literature, they were divided into two groups: primary and secondary benefits. For secondary benefits to be perceived, some primary benefits must be achieved. In other words, secondary benefits are consequences of primary benefits. Chart 1 lists the benefits that have been classified as either primary or secondary, organizing them from the most to the least cited.

Chart 1. Benefits.

\begin{tabular}{|c|c|c|c|}
\hline & \multicolumn{3}{|c|}{ BENEFITS } \\
\hline \multirow{11}{*}{$\frac{\sum}{a}$} & Better inventory management (84\%) & \multirow{11}{*}{ 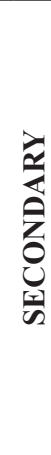 } & Cost reduction $(67 \%)$ \\
\hline & Better demand predictability $(50 \%)$ & & Better level of customer service (54\%) \\
\hline & Improved replenishment process $(50 \%)$ & & Increase in sales $(38 \%)$ \\
\hline & Better production cycle $(30 \%)$ & & Profit increase $(23 \%)$ \\
\hline & Reduced cycle time $(26 \%)$ & & Improvement of competitiveness $(18 \%)$ \\
\hline & Improved relationship (24\%) & & Better asset management (14\%) \\
\hline & Improved supply chain management (20\%) & & Improved financial performance $(13 \%)$ \\
\hline & Improved product assortment $(9 \%)$ & & Greater customer responsiveness (8\%) \\
\hline & Improved product launch efficiency $(9 \%)$ & & - \\
\hline & Improvement of promotional activities $(8 \%)$ & & - \\
\hline & Better planning $(4 \%)$ & & - \\
\hline
\end{tabular}

Source: Prepared by the authors. 


\subsection{Barriers}

The analysis of the barriers to collaborative initiatives identified in the systematic literature review revealed that it is pertinent to categorize them as behavioral, cultural, and physical based on the works of Freitas et al. (2013, 2014). According to these authors, behavioral barriers are related to the companies' willingness to collaborate in a supply chain; cultural barriers, on the other hand, are related to the organizational culture, and they influence the implementation and maintenance of $\mathrm{e}$ initiatives. Lastly, physical barriers are related to the technology and resources that are needed to implement initiatives. Chart 2 lists the various barriers that have been classified as behavioral, cultural, and physical, organizing them according to their importance based on how often they have been cited.

\subsection{Motivators}

The analysis of the motivators of adopting the studied collaborative initiatives led to categorizing them into two groups: economic or market motivators and organizational motivators. The economic or market motivators are external factors influencing a supply chain. These motivators are produced by an economic movement or a market event that encourages companies to adopt collaborative initiatives as a reaction to changes. Organizational motivators, on the other hand, are internal factors influencing a supply chain. They are related to the form of organization of companies, both internally and among companies, which lead to the adoption of collaborative initiatives. Chart 3 lists the motivators, which have been classified as either economic or market motivators or organizational motivators arranged according to their frequency of being cited.

\section{Proposition of theoretical structure}

From the theory that was analyzed, it was possible to develop a theoretical framework to assist the decision-making process of adopting a collaborative initiative in SCM (Figure 4). This structure consolidates the aforementioned elements in a logical sequence that will allow making choice more appropriate to the needs and reality of companies and studies in this field.

When analyzing the enterprise environment, it is necessary to observe changes in the economy or events in the market that can provoke an unbalanced supply chain, that is, economic or market motivators, which can foster the implementation of one or more

Chart 2. Barriers.

\section{BARRIERS}

Lack of training for new mentalities and skills (46\%)

Divergent goals and targets (38\%)

Lack of a relationship orientation (33\%)

Lack of ability to share risks and rewards (33\%)

Difficulties in the integration of key processes (32\%)

Inflexible organizational processes and systems (31\%)

Inconsistent / inadequate performance measures (31\%)

Lack of support from top management (31\%)

Lack of cross-functional coordination $(25 \%)$

Incompatible organizational culture (24\%)

Lack of formalization of processes and documents (14\%)

Lack of joint planning (14\%)

Lack of focus on meeting customer needs (13\%)

Individual problem solving and decision making (4\%)

Lack of trust (52\%)
Inability or unwillingness to share information
$(50 \%)$
Problems in the flow of information and
communication $(35 \%)$
Resistance to change $(27 \%)$
Lack of commitment $(20 \%)$
Insufficient IT / IS / telecom investment (63\%)
Insufficient financial investments $(17 \%)$
Other insufficient investments $(15 \%)$

Source: Prepared by the authors.

Chart 3. Motivators.

\begin{tabular}{ll}
\hline ECONOMIC OR MARKET & MOTIVATORS \\
\hline ORGANIZATIONAL & More intense competition $(71 \%)$ \\
& Demand/product/market characteristics $(44 \%)$ \\
& Economic globalization $(24 \%)$ \\
Market reaction $(15 \%)$ \\
Supply chain problems $(50 \%)$ \\
Previous experiences $(24 \%)$ \\
Pressure from a commercial partner $(18 \%)$ \\
\hline
\end{tabular}

Source: Prepared by the authors. 


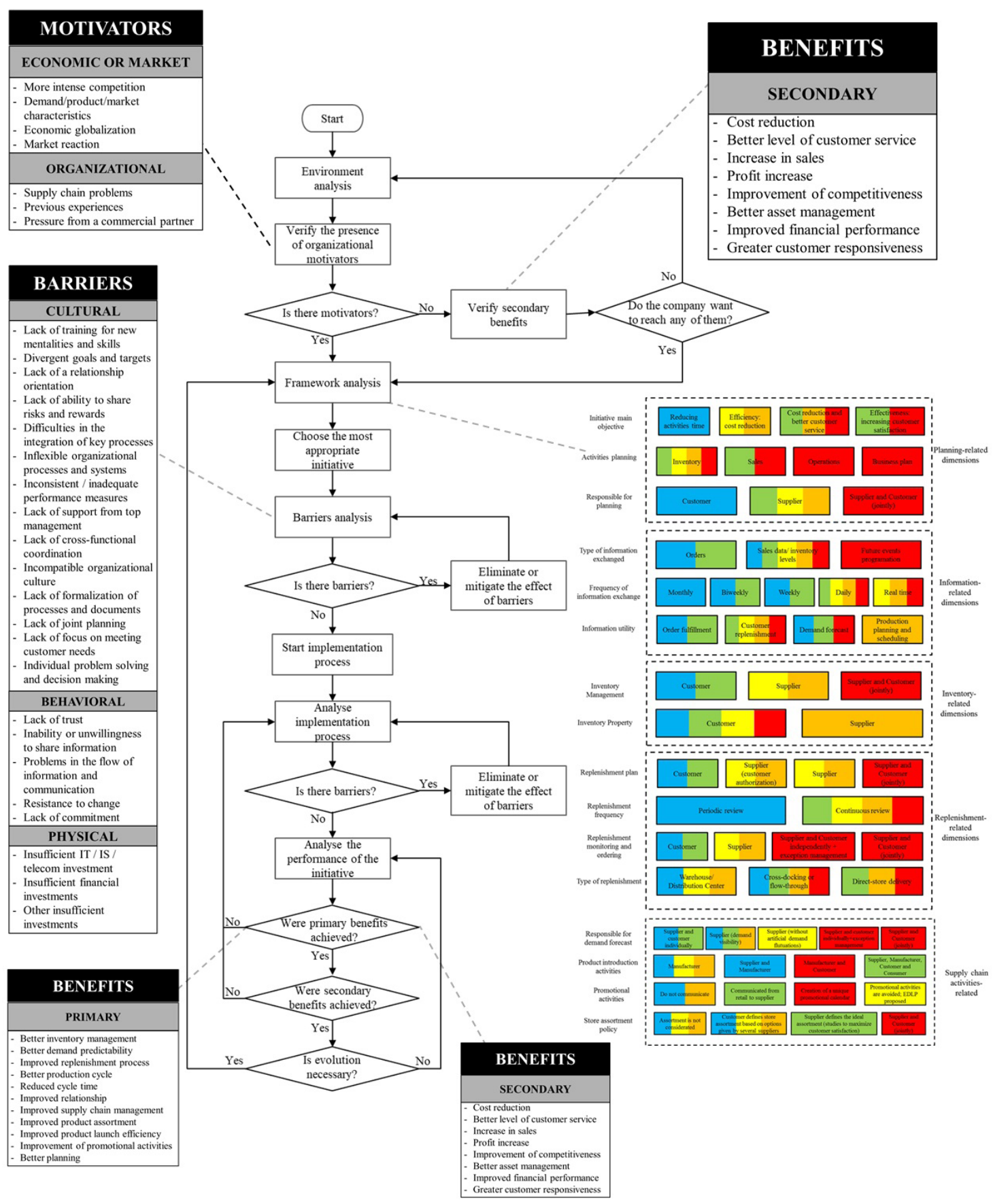

Figure 4. Theoretical structure to support the decision to adopt collaborative initiatives. Source: Prepared by the authors.

collaborative initiatives. Moreover, by internally analyzing a supply chain and its structure and organization, a company must verify the presence of organizational motivators that can foster the adoption of a collaborative initiative.

Increased competition and globalization are external factors that can motivate companies to shift their focus to their supply chains. Moreover, changes in the characteristics of demand, product or market, such as reduced product lifecycles, increased customer requirements, increased facilities, and government policies, can also lead companies to collaborate with their supply chains to maintain the market. Another external motivator is the perception of the need to follow the market in terms of tools and technologies to preserve the commercial position of a company.

With respect to organizational motivators, the perception of problems that are affecting supply chain performance, such as high response time, high inventory levels, inadequate cost structure, 
outdated business processes or demand forecasting difficulties, can drive companies to implement a collaborative initiative. Furthermore, the success of previous collaborative experiences with management practices, the possibility of taking advantage of the communication infrastructure, and the innovative tendency of companies, seeking ways to differentiate themselves competitively, facilitates the introduction of collaborative initiatives. Pressure from an influential trading partner can also lead a company to adopt an initiative to tighten or maintain its trade relations.

The recognition by companies that collaborative initiatives can result in increased sales and profit, reduced costs, greater customer responsiveness, better asset management, improved financial, and competitive performances can also stimulate the beginning of a collaborative relationship. After choosing the most appropriate collaborative initiative, it is necessary to detect the presence of barriers that may hinder the implementation or the achievement of the expected benefits. Furthermore, analyzing the barriers may highlight the need for cultural changes in a company, behavioral changes of people or even the need for investments to advance the collaborative relationship. After the initiative has been implemented, it is important to analyze its performance to ensure that the primary and secondary benefits are being achieved.

With the evolution of the collaborative relationship, one can perceive the need for a more complete initiative that increases collaboration between agents. In this case, the theoretical framework allows us to verify the collaborative level among partners in a supply chain. With this, it is possible to delineate an expected future state with the development of the relationship. Thus, the new configuration for the desired initiative is prospected, and the cycle resumes with the analysis of the barriers that may limit the adoption of a new initiative.

\section{Final considerations}

The general objective of this study was to propose a theoretical framework to guide the decision-making process of adopting and implementing collaborative SCM initiatives, specifically QR, ECR, CRP, VMI, and CPFR, based on their characteristics, expected benefits, motivators, and possible barriers. A theoretical structure was created, presenting a sequence of actions and decisions, relating the main results of this work. This tool is very important, as it outlines the main aspects that must be considered by both managers and researchers before adopting a collaborative initiative to ensure its success. Furthermore, this tool highlights the need to constantly monitor the collaborative relationship vis-à-vis the desired initial goals.

Figure 3 assists in characterizing the collaborative initiatives by presenting dimensions that differentiate each initiative and indicates that an initiative can have several possible configurations, depending on the peculiarities of each relationship. It also presents a scale of the level of collaboration, showing that there is one practice that is better than others in all dimensions. This implies that a certain initiative may have evolved greatly in some dimension in comparison to other aspects.

The present study has an exploratory, theoretical character and was able to contribute to the systematization of existing knowledge related to the studied collaborative initiatives, namely, QR, ECR, CRP, VMI, and CPFR. However, the results of this work must be validated and empirically improved - this can be considered as a limitation of this work. This initial exploratory study paves the way for several research fronts, initially with the validation of its framework (Figure 3), the identified benefits (Chart 1), barriers (Chart 2), and motivators (Chart 3) and later with the validation of its theoretical framework to assist the decision-making process of initiating a collaborative relationship (Figure 4). The flowchart developed in this study can be improved by conversing with professionals directly involved in the implementation of collaborative initiatives, adding factors that are considered in the decision-making process that were not represented here.

\section{References}

Alftan, A., Kaipia, R., Loikkanen, L., \& Spens, K. (2015). Centralised grocery supply chain planning: improved exception management. International Journal of Physical Distribution \& Logistics Management, 45(3), 237-259.

Alvarado, U. Y., \& Kotzab, H. (2001). Supply chain management: the integration of logistics in marketing. Industrial Marketing Management, 30(2), 183-198. http://dx.doi.org/10.1016/S0019-8501(00)00142-5.

Aspargi, N., Nikbakhsh, E., Hill, A., \& Farahani, R. Z. (2016). Supply chain management 1982-2015: a review. Journal of Management Mathematics, 27(3), 353-379. http://dx.doi.org/10.1093/imaman/dpw004.

Barratt, M., \& Oliveira,A. (2001). Exploring the experiences of collaborative planning initiatives. International Journal of Physical Distribution \& Logistics, 31(4), 266-289. http://dx.doi.org/10.1108/09600030110394932.

Birtwistle, G., Siddiqui, N., \& Fiorito, S. S. (2003). Quick response: perceptions of UK fashion retailers. International Journal of Retail \& Distribution Management, 31(2), 118-128. http://dx.doi.org/10.1108/09590550310462010.

Buchinger, D., Cavalcanti, G. A. S., \& Hounsell, M. S. (2014). Mecanismos de busca acadêmica: uma análise quantitativa. Revista Brasileira de Computação Aplicada, 6(1), 108-120. http://dx.doi.org/10.5335/rbca.2014.3452.

Cao, M., \& Zhang, Q. (2011). Supply chain collaboration: impact on collaborative advantage and firm performance. 
Journal of Operations Management, 29(3), 163-180. http://dx.doi.org/10.1016/j.jom.2010.12.008.

Carle, M. A., Martel, A., \& Zufferey, N. (2012). The CAT metaheuristic for solution of multi-period activity -based supply chain network design problems. International Journal of Production Economics, 139(2), 664-677. http://dx.doi.org/10.1016/j.ijpe.2012.06.016.

Castro, M. R., \& Ladeira, M. B. (2012). Práticas colaborativas na cadeia de suprimentos e o papel das novas tecnologias de informação. E-tech: Tecnologias para a Competitividade Industrial, 5(1), 32-55. http:// dx.doi.org/10.18624/e-tech.v5i1.252.

Chan, F. T. S., \& Zhang, T. (2011). The impact of collaborative transportation management on supply chain performance: a simulation approach. Expert Systems with Applications, 38(3), 2319-2329. http:// dx.doi.org/10.1016/j.eswa.2010.08.020.

Choi, T.-M., \& Sethi, S. (2010). Innovative quick response programs: a review. International Journal of Production Economics, 127(1), 1-12. http://dx.doi.org/10.1016/j. ijpe.2010.05.010.

Chong, A. Y. L., Ooi, K. B., \& Sohal, A. (2009). The relationship between supply chain factors and adoption of e-Collaboration tools: an empirical examination. International Journal of Production Economics, 122(1), 150-160. http://dx.doi.org/10.1016/j.ijpe.2009.05.012.

Colicchia, C., \& Strozzi, F. (2012). Supply chain risk management: a new methodology for a systematic literature review. Supply Chain Management, 17(4), 403-418. http://dx.doi.org/10.1108/13598541211246558.

Denyer, D., \& Tranfield, D. (2009). Producing a systematic review. In D. Buchanan \& A. Bryman (Eds.), The sage handbook of organizational research methods (pp. 671689). Thousand Oaks: Sage Publishing.

Derrouiche, R., Neubert, G., \& Bouras, A. (2008). Supply chain management: a framework to characterize the collaborative strategies. International Journal of Computer Integrated Manufacturing, 21(4), 426-439. http://dx.doi.org/10.1080/09511920701574461.

Ellram, L. M., \& Cooper, M. C. (1990). Supply chain management, partnership and the shipper: third party relationship. International Journal of Logistics Management, 1(2), 1-10. http://dx.doi.org/10.1108/95740939080001276.

Elvander, M. S., Sarpola, S., \& Mattsson, S.-A. (2007). Framework for characterizing the design of VMI systems. International Journal of Physical Distribution \& Logistics Management, 37(10), 782-798. http://dx.doi. org/10.1108/09600030710848914.

Esper, T. L., Ellinger, A. E., Stank, T. P., Flint, D. J., \& Moon, M. (2010). Demand and supply integration: a conceptual framework of value creation through knowledge management. Journal of the Academy of Marketing Science, 38(1), 5-18. http://dx.doi.org/10.1007/ s11747-009-0135-3.
Fawcett, S. E., Magnan, G. M., \& McCarter, M. W. (2008). Benefits, barriers, and bridges to effective supply chain management. Supply Chain Management, 13(1), 35-48. http://dx.doi.org/10.1108/13598540810850300.

Fischl, M., Scherrer-Rathje, M., \& Friedli, T. (2014). Digging deeper into supply risk: a systematic literature review on price risks. Supply Chain Management, 19(5-6), 480-503. http://dx.doi.org/10.1108/SCM-12-2013-0474.

Forza, C., \& Vinelli, A. (1997). Quick response in the textile-apparel industry and the support of information technologies. Integrated Manufacturing Systems, 8(3), 125-136. http://dx.doi.org/10.1108/09576069710181947.

Francis, M., Simons, D., \& Bourlakis, M. (2008). Value chain analysis in the UK beef food service sector. Supply Chain Management, 13(1), 83-91. http://dx.doi. org/10.1108/13598540810850346.

Freitas, D. C. (2015). Estrutura teórica para a adoção de iniciativas de colaboração em cadeias de suprimentos (Dissertação de mestrado). Universidade Federal de São Carlos, São Carlos.

Freitas, D. C., Oliveira, L. G., \& Alcântara, R. L. C. (2018). Collaborative initiatives: motivators, barriers and benefits. Revista de Administração Mackenzie, 19(3), 1-25. http://dx.doi.org/10.1590/1678-6971/eramr170126.

Freitas, D. C., Tomas, R. N., \& Alcantara, R. L. C. (2013). Estoque gerenciado pelo fornecedor (VMI): análise das barreiras e fatores críticos de sucesso em empresas de grande porte. Revista de Administração da UNIMEP, 11(3), 221-252. http://dx.doi.org/10.15600/1679-5350/ rau.v11n3p221-252.

Freitas, D. C., Tomas, R. N., \& Alcântara, R. L. C. (2014). Análise da prática Vendor Managed Inventory (VMI) em um fornecedor de bens de consumo. Produção Online, 14(3), 1024-1049. https://doi.org/10.14488/1676-1901. v14i3.1654.

Fu, H. P. (2016). Comparing the factors that influence the adoption of CPFR by retailers and suppliers. International Journal of Logistics Management, 27(3), 931-946. http:// dx.doi.org/10.1108/IJLM-10-2014-0168.

Gao, X., Liu, J., \& Liu, D. (2005). Supply chain coordination: a review. Journal of Systems Science and Information, 3(3), 569-584.

Goldsby, T. J., \& García-Dastugue, S. (2003). The manufacturing flow management process. International Journal of Logistics Management, 14(2), 33-52. http:// dx.doi.org/10.1108/09574090310806585.

Gomes, L. C., \& Kleimann, F. J., No. (2015). Métodos colaborativos na gestão de cadeias de suprimentos: desafios de implementação. Revista de Administração de Empresas, 55(5), 563-577. http://dx.doi.org/10.1590/ S0034-759020150508.

Holmström, J., Främling, K., Kaipia, R., \& Saranen, J. (2002). Collaborative planning forecasting and replenishment: new solutions needed for mass collaboration. Supply 
Chain Management, 7(3), 136-145. http://dx.doi. org/10.1108/13598540210436595.

Holweg, M., Disney, S., Holmström, J., \& Småros, J. (2005). Supply chain collaboration: making sense of the strategy continuum. European Management Journal, 23(2), 170-181. http://dx.doi.org/10.1016/j.emj.2005.02.008.

Hudnurkar, M., \& Rathod, U. (2012). Collaborative supply chain: insights from simulation. International Journal of System Assurance Engineering and Management, 3(2), 122-144. http://dx.doi.org/10.1007/s13198-012-0114-9.

Jiao, J., Zhang, Y., \& Wang, Y. (2007). A generic genetic algorithm for product family design. Journal of Intelligent Manufacturing, 18(2), 233-247. http://dx.doi.org/10.1007/ s10845-007-0019-7.

Kotzab, H. (1999). Improving supply chain performance by efficient consumer response? A critical comparison of existing ECR approaches. Journal of Business and Industrial Marketing, 14(5), 364-377. http://dx.doi. org/10.1108/08858629910290111.

Kozlenkova, I. V., Hult, G. T. M., Lund, D. J., Mena, J. A., \& Kekec, P. (2015). The role of marketing channels in supply chain management. Journal of Retailing, 91(4), 586-609. http://dx.doi.org/10.1016/j.jretai.2015.03.003.

Kurnia, S., \& Johnston, R. B. (2003). Adoption of efficient consumer response: key issues and challenges in Australia. Supply Chain Management, 8(3), 251-262. http://dx.doi. org/10.1108/13598540310484645.

Lakshmanasamy, T., \& Anil, C. (2015). The effect of attributes of distribution channel member on supply chain management: an empirical analysis of social network in business. International Journal of Logistics Systems and Management, 21(2), 160-180. http://dx.doi. org/10.1504/IJLSM.2015.069373.

Lee, S. C., Pak, B. Y., \& Lee, H. G. (2003). Business value of B2B electronic commerce: the critical role of interfirm collaboration. Electronic Commerce Research and Applications, 2(4), 350-361. http://dx.doi.org/10.1016/ S1567-4223(03)00003-6.

Lima, C., Relvas, S., \& Barbosa-Póvoa, A. P. F. D. (2016). Downstream oil supply management: a critical review and future directions. Computers \& Chemical Engineering, 92, 78-92. http://dx.doi.org/10.1016/j. compchemeng.2016.05.002.

Marqui, A. C., Moura, K. S., \& Alcântara, R. L. C. (2013). Collaborative supply chain: a conceptual model for operationalisation. International Journal of Management and Decision Making, 12(3), 195-214. http://dx.doi. org/10.1504/IJMDM.2013.056458.

Melo, D. C., \& Alcântara, R. L. C. (2016). O que torna a gestão da demanda na cadeia de suprimentos possível? Um estudo multicaso dos fatores críticos de sucesso. Gestão \& Produção, 23(3), 570-587. http://dx.doi. org/10.1590/0104-530x2023-15.

Mentzer, J. T., \& Gundlach, G. (2010). Exploring the relationship between marketing and supply chain management: introduction to the special issue. Journal of the Academy of Marketing Science, 38(1), 1-7. http:// dx.doi.org/10.1007/s11747-009-0150-4.

Mentzer, J. T., DeWitt, W., Keebler, J. S., Min, S., Nix, N. W., Smith, C. D., \& Zacharia, Z. G. (2001). Defining supply chain management. Journal of Business Logistics, 22(2), 1-25. http://dx.doi.org/10.1002/j.2158-1592.2001. tb00001.x.

Mentzer, J. T., Min, S., \& Zacharia, Z. G. (2000). The nature of interfirm partnering in supply chain management. Journal of Retailing, 76(4), 549-568. http://dx.doi. org/10.1016/S0022-4359(00)00040-3.

Moura, K. S. (2013). Colaboração na gestão da cadeia de hortifruti: um estudo sobre o relacionamento fornecedorvarejista supermercadista (Dissertação de mestrado). Universidade Federal de São Carlos, São Carlos.

Nyaga, G. N., Whipple, J. M., \& Lynch, D. F. (2010). Examining supply chain relationships: do buyer and supplier perspectives on collaborative relationships differ? Journal of Operations Management, 28(2), 101-114. http://dx.doi.org/10.1016/j.jom.2009.07.005.

Ogunlela, G. O., \& Lekhanya, L. M. (2016). The use of integrated supply chain management model for promoting competitiveness in the fast moving consumer goods (FMCG) manufacturing industry in Nigeria. Problems and Perspectives in Management, 14(1), 160-167. http:// dx.doi.org/10.21511/ppm.14(1-1).2016.03.

Okoli, C., \& Schabram, K. (2010). A guide to conducting a systematic literature review of information systems research. Sprouts: Working Papers on Information Systems, 10(26), 10-26.

Panahifar, F., Heavey, C., Byrne, P. J., \& Fazlollahtabar, H. (2015). A framework for Collaborative Planning, Forecasting and Replenishment (CPFR): state of the art. Journal of Enterprise Information Management, 28(6), 839-871.

Perry, M., \& Sohal, A. S. (2000). Quick response practices and technologies in developing supply chains: a case study. International Journal of Physical Distribution \& Logistics, 30(7-8), 627-639. http://dx.doi. org/10.1108/09600030010346369.

Raghunathan, S., \& Yeh, A. B. (2001). Beyond EDI: impact of Continuous Replenishment Program (CRP) between a manufacturer and its retailers. Information Systems Research, 12(4), 406-419. http://dx.doi.org/10.1287/ isre.12.4.406.9701.

Ramanathan, U. (2014). Performance of supply chain collaboration: a simulation study. Expert Systems with Applications, 41(1), 210-220. http://dx.doi.org/10.1016/j. eswa.2013.07.022.

Sari, K. (2008). Inventory inaccuracy and performance of collaborative supply chain practices. Industrial Management \& Data Systems, 108(4), 495-509. http:// dx.doi.org/10.1108/02635570810868353. 
Seuring, S., \& Gold, S. (2012). Conducting content-analysis based literature reviews in supply chain management. Supply Chain Management, 17(5), 544-555. http:// dx.doi.org/10.1108/13598541211258609.

Stank, T. P., Daugherty, P. J., \& Autry, C. W. (1999). Collaborative planning: supporting automatic replenishment programs. Supply Chain Management, 4(2), 75-85. http:// dx.doi.org/10.1108/13598549910264752.

Tanaca, E. K. T., Souza Filho, H. M., \& Ganga, G. M. D. (2014). Proposta de um modelo de avaliação dos fornecedores do Programa de Aquisição de Alimentos (PAA): o caso do município de São Carlos - SP. Gestão \& Produção, 21(4), 781-792. http://dx.doi. org/10.1590/0104-530X149-12.

Torraco, R. J. (2005). Writing integrative literature reviews: guidelines and examples. Human Resource Development Review, 4(3), 356-367. http://dx.doi. org/10.1177/1534484305278283.

Vallet-Bellmunt, T., Martínez-Fernández, M. T., \& Capó-Vicedo, J. (2011). Supply chain management: a multidisciplinary content analysis of vertical relations between companies, 1997-2006. Industrial Marketing Management, 40(8), 1347-1367. http://dx.doi.org/10.1016/j. indmarman.2011.03.002.

Vigtil, A., \& Dreyer, H. C. (2008). Critical aspects of information and communication technology in vendor managed inventory. In T. Koch (Eds.), Lean business systems and beyond. IFIP - The International Federation for Information Processing (Vol. 257, pp. 1-8). Boston: Springer.

vom Brocke, J., Simons, A., Niehaves, B., Riemer, K., Plattfaut, R., \& Cleven, A. (2009). Reconstructing the giant: on the importance of rigour in documenting the literature search process. In Proceedings of the 17th European Conference on Information Systems (ECIS). USA: Association for Information Systems. Retrieved in 2017, July 31, from http://is2.1se.ac.uk/ asp/aspecis/20090183.pdf

Whipple, J. M., \& Russell, D. (2007). Building supply chain collaboration: a typology of collaborative approaches. International Journal of Logistics Management, 18(2), 174-196. http://dx.doi.org/10.1108/09574090710816922.

Wong, C., Skipworth, H., Godsell, J., \& Achimugu, N. (2012). Towards a theory of supply chain alignment enablers: a systematic literature review. Supply Chain Management, 17(4), 419-437. http://dx.doi. org/10.1108/13598541211246567.

Yang, D., Qi, E., \& Li, Y. (2015). Quick response and supply chain structure with strategic consumers. Omega, 52, 1-14. http://dx.doi.org/10.1016/j.omega.2014.10.006.

Yao, Y., Dong, Y., \& Dresner, M. E. (2007). Analyzing information-enabled stockout management under vendor-managed inventory. Information Technology and Management, 8(2), 133-145. http://dx.doi.org/10.1007/ s10799-007-0009-7. 